\title{
CONSTRUCTING A SOCIAL ACCOUNTING MATRIX TO ADDRESS INCOME DISTRIBUTION ISSUES IN MALAYSIA
}

\author{
MASOUD YAHOO \\ ZAKARIAH A. RASHID \\ Malaysian Institute of Economics Research (MIER) \\ Kuala Lumpur \\ MOHAMMAD MAHDI KIAEEHA \\ FATEMEH CHATRI \\ School of Economics \\ Faculty of Economics and Management \\ Universiti Kebangsaan Malaysia
}

\begin{abstract}
The Malaysian economy has undergone sound growth over the past three decades. During the 1990s, the government designed a vision to become a high-income developed nation by 2020. Strengthening aggregate demand within a developing economy such as Malaysia's is critical for achieving this target. In quantifying the impact of such measures economists have employed the social accounting matrix as an analytical tool. The challenge associated with the construction of a social accounting matrix for Malaysia, especially when up-to-date databases are not readily available, is the main issue addressed by this paper. The constructed matrix can provide an updated country-wide data source for use in policy analysis and as a database for macroeconomic modelling purposes. The applied database investigates the key economic sectors contributing to Malaysia's economic growth and income distribution between three household types. This paper presents the first attempt in this direction employing recently published input-output tables and complemented with updated data from different sources.
\end{abstract}

Keywords: Social Accounting Matrix, Government expenditure, Income distribution, Multiplier analysis, Malaysia. 


\section{Introduction}

Malaysia's Gross Domestic Product (GDP) increased by 6\% in 2014 compared to $5.6 \%$ and $4.7 \%$ in 2012 and 2013, respectively (Central Bank of Malaysia, 2014). Figure 1 on Malaysia's economic indicators from 2008 to 2014 clearly shows that domestic demand has been the key driver of the country's economic growth with private investment out-weighing the role of public investment since 2012. In terms of private consumption, rationalising the fuel subsidy in mid-2013 and other administrated price adjustments significantly increased the cost of living, although this was somewhat offset by transfer payments to low and middle-income households which to some extent eased the negative impact of commodity price increase on household consumption. Nevertheless, private consumption which contributes substantially to GDP growth is currently experiencing a declining growth rate. On the public component of total domestic demand, the government's cost-cutting initiatives led to a lower public consumption rate (4.4\% in 2014 compared to $6.3 \%$ in 2013). It is noteworthy that the $4.9 \%$ decline in public investment led to aggregate investment growing at a lower rate of $4.7 \%$ between 2013 and 2014 , compared to $8.5 \%$ in the $2012-2013$ period. The $4.9 \%$ growth rate in public investment reflects government disinvestment in the economy in 2014 (Central Bank of Malaysia, 2014).

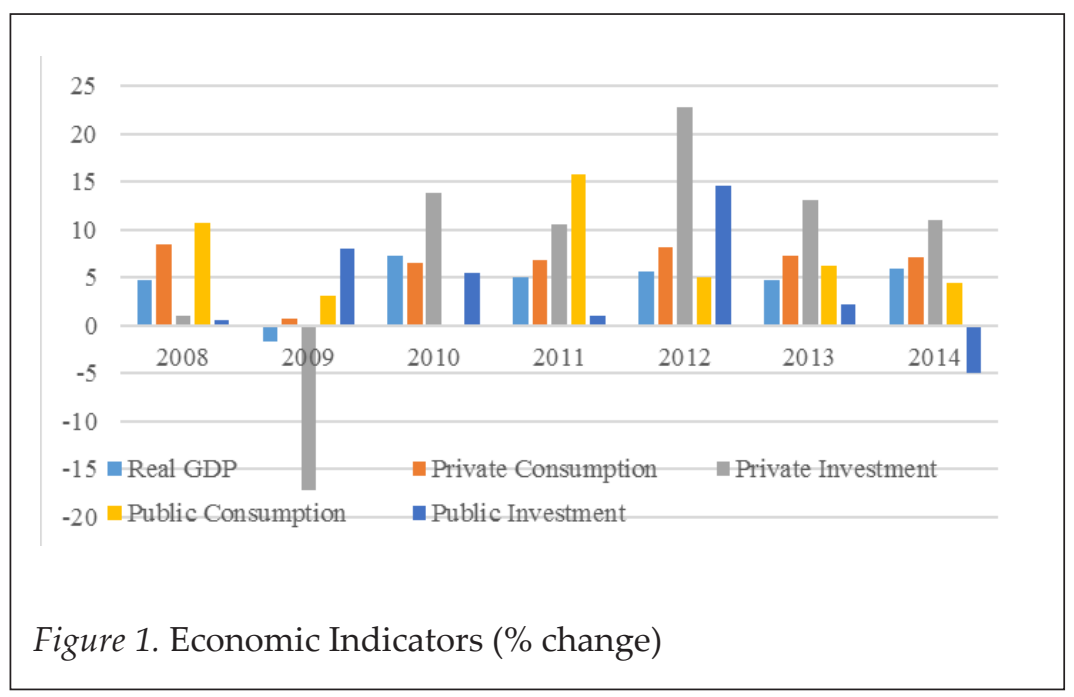

Source. Central Bank of Malaysia (2014) 
Figure 2 on the sectoral contributions to the Malaysian economy for 2000 and 2014 shows that while the share of manufacturing declined, service-based activities dominated GDP growth while the share of mining, agriculture, and construction remained mostly the same. Malaysia is trying to become a high-income economy as pledged in Vision 2020 (Economic Planning Unit, 2001) and the government is actively exploring ways to stimulate investments or providing better infrastructure facilities aimed at boosting investment opportunities within the country.

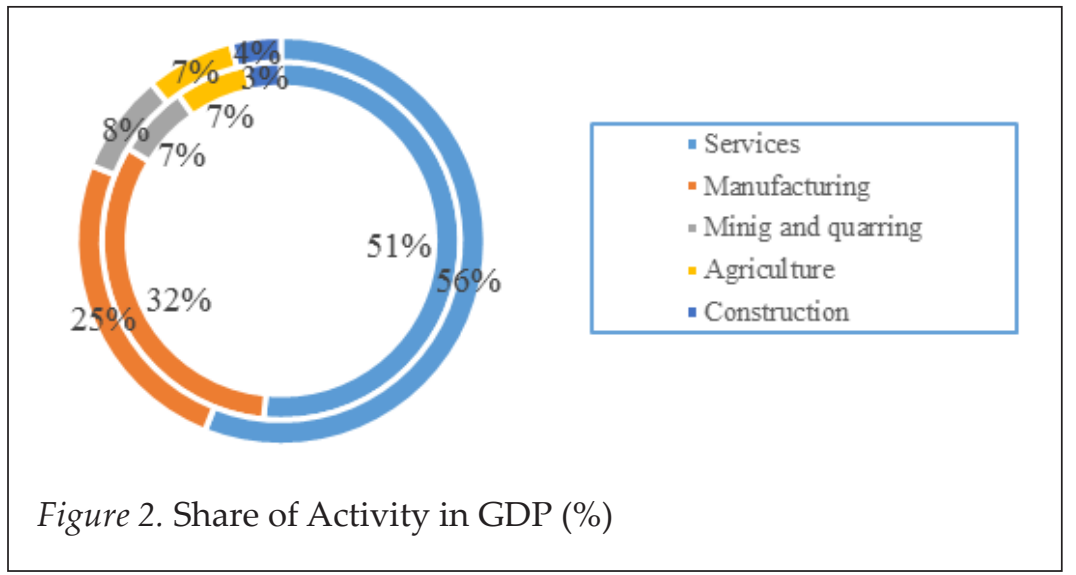

Source: Department of Statistics (2016)

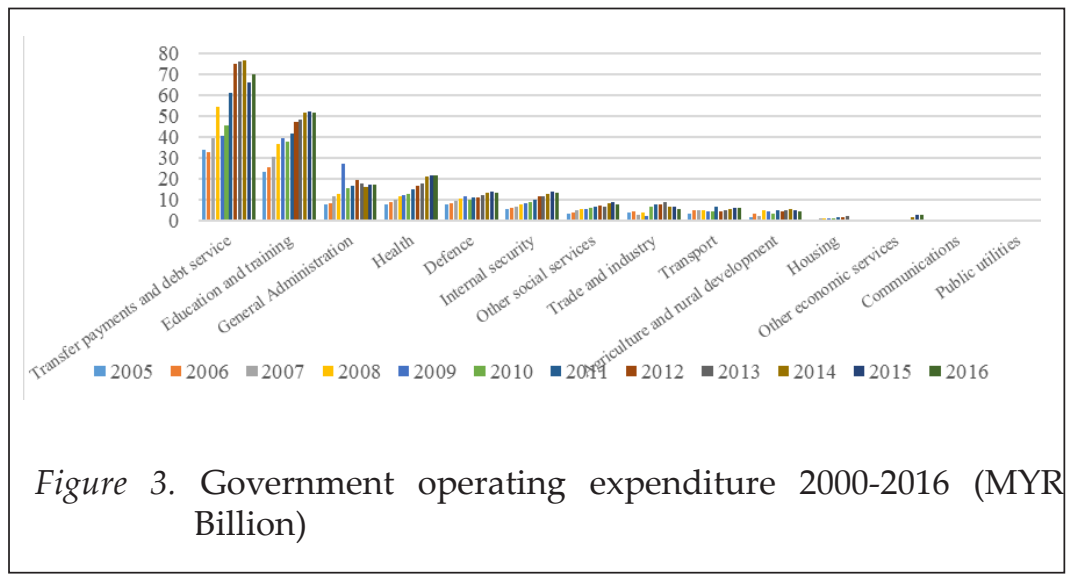

Source. Ministry of Finance (2016) 
Figures 3 and 4 show the Malaysian government's operating and development expenditures from 2005 to 2016, based on data from the Ministry of Finance Malaysia (2016). ${ }^{1}$ As Figure 3 shows, allocations for transfer payments and education were the highest, followed by public administration and health. Average total public expenditure growth rates declined from $12.5 \%$ over the $2011-2012$ period to $4 \%$ in 2013-2014 (Ministry of Finance Malaysia, 2016). Due to income distribution concerns, as shown in Figure 3, the growth in transfer payments increased from $21.1 \%$ over $2006-2007$ to $34.3 \%$ in $2010-2011$.

To highlight the income distribution effects from the increase in transfer payments, Table 1 compares the Gini coefficient for three different years. Comparing the percentage changes in transfer payments and the Gini measurement shows that the significant increase in public expenditure was not accompanied by a substantial reduction in Malaysian household income inequalities, although the 0.03 decline from 0.43 in 2012 to 0.4 in 2014 indicates some improvement in that direction (Department of Statistics, 2015b). Analysing the corresponding coefficients across different household groups showed that the same pattern can also be seen in urban and rural strata, and thus raising the question of whether appropriate means have been used for transfer payments to assist the lower quartile of the population.

Table 1

Gini coefficient by Strata

\begin{tabular}{llcl}
\hline Group/Year & 2009 & 2012 & 2014 \\
\hline Malaysia & 0.44 & 0.43 & 0.4 \\
Urban & 0.42 & 0.41 & 0.39 \\
Rural & 0.4 & 0.38 & 0.35 \\
\hline
\end{tabular}

Source. Department of Statistics (2015)

As shown in Figure 4, although the transport sector's share of development expenditure for 2009 and 2010 is lower than that of the education sector, it is higher than that for other sectors in other years. The education and transport sectors have received the bulk of public sector development expenditure, reflecting their importance to the Malaysian economy. It should be noted that although total development expenditure declined by $7.6 \%$ in 2013 as compared to 
2012, it increased by about 20\% from 2014 to 2015, and is projected (at that time) to increase by $7.5 \%$ between 2015 and 2016. An important feature of the government's operating and development expenditures is the large allocation to education which often dominates the share received, especially in the development expenditures category (Central Bank of Malaysia, 2014)

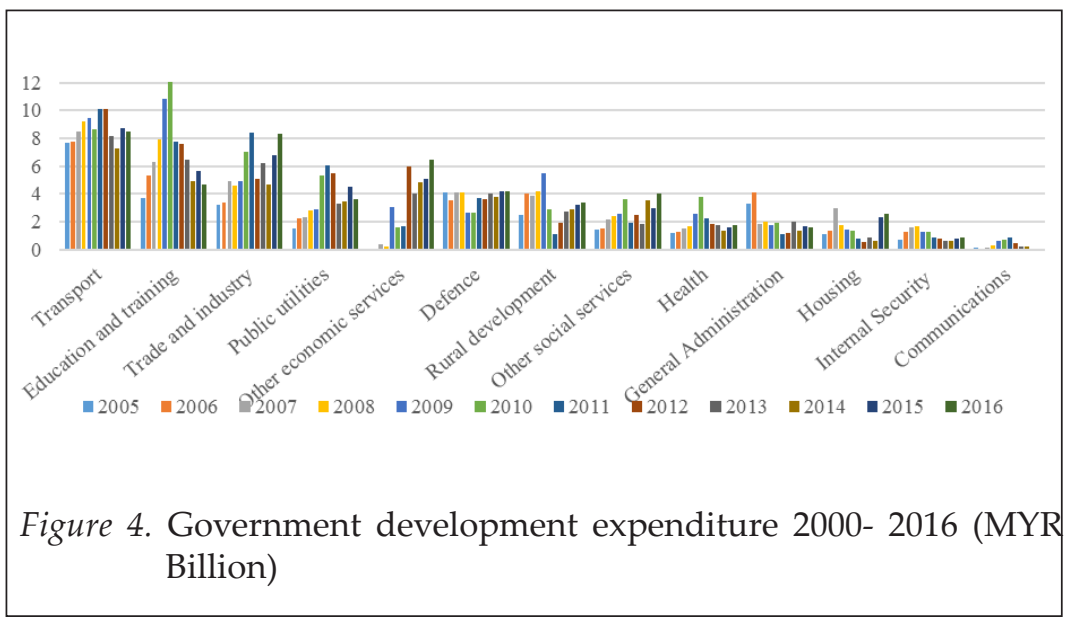

Source. Ministry of Finance (2016)

Meanwhile, different stages had been identified in the Tenth Malaysia Plan 2011-2015 for major structural transformation shifts that would turn Malaysia into a high-income country (Economic Planning Unit, 2011). Stimulating aggregate demand is among the major instruments of fiscal policy to spur economic growth in reaching the targets of the plan. An initiatives by the government in this area includes the New Economic Model (NEM) developed by the National Economic Advisory Council and inaugurated by the prime minister in 2009 (National Economic Advisory Council, 2010). To assess the expected quantitative effects of different plans and policies on the Malaysian economy, an updated Social Accounting Matrix (SAM) as a reference for the policy simulations needs to be constructed.

A social accounting matrix is considered a desirable analytical tool for providing quantitative analysis since it provides feedback on the relationships between different agents and sectors of the economy. In other words, SAM is a technique that captures national income accounting and provides a conceptual basis for analysing both growth and distributional issues within a single analytical framework 
in an economy. It presents the interaction between production, factor incomes, intermediate and final consumption, and investmentsaving linkages in a single matrix framework. This paper constructs a SAM framework for the Malaysian economy that will highlight the macroeconomic, sectoral, and income distributional impacts of an expansion in final demand.

Furthermore, since the SAM framework is not only a statistical tool but also a framework for macroeconomic analysis, the constructed SAM divides government expenditures into two categories, i.e., consumption and investment expenditures, and attempts to shed light on the importance of government expenditure in the Malaysian economy. However, until now, there had only been a few social accounting matrices developed for Malaysia that encapsulate some of its economic complexities. The last framework prepared by Zakariah, Mukarammah, and Azali (2012) did not reflect the major structural changes that occurred in the Malaysian economy since then. The constructed framework provides a picture of the complexity of the economy for the year 2000. The macroeconomic and distributional impacts of the stimulation of final demand can be addressed by applying SAM, as described in this paper. Policymakers need to be fully aware of the impacts of any changes in policies, and developing an updated and disaggregated data framework can facilitate understanding of how and to what extent, different economic policies and plans may affect different factors of production and the various income groups. Specifically, this paper sought to answer the following research questions: (a) which production factor will receive higher income in turn of supply, (b) which sectors will generate this income, (c) which household groups and the extent to which they will receive factor incomes, and (d) how an increase in final demand will affect GDP across sectors and help income distribution among different household types.

\section{Literature Review}

The equality of supply and demand in various markets and the circular flow of income between different economic agents are shown in SAM. Although SAMs can be traced to the Economic Table presented by Quesnay (1758) as explained by Kehoe (1996), the contributions of Kuznets (1937), Meade and Stone (1941), and Leontief (1941) provided the foundation for Stone (1947) to develop the basis for the well-known United Nations System of National Accounts (UNSNA). Following that, Stone (1962) developed the first 
SAM for the UK economy in Stone and Brown (1962) to analyse the impact of different scenarios in UK economic growth (Ramanathan, 2012). The extension and application of SAM techniques were then expanded for addressing poverty and income distribution issues across developing countries (Round, 2003). Since then, the SAM framework has been applied in an increasing number of countries. Pyatt and Round (1979) construed a SAM matrix for Sri Lanka and applied it for multiplier analysis. Chander, Gnasegarah, Pyatt, and Round (1980), Round (1981), and Pyatt, Round, and Denes (1984) ${ }^{2}$ formulated SAM for Malaysia, Defourny and Thorbecke (1984) for Korea, Thorbecke (1992), and Keuning, Thorbecke, and Morrison (1989) for Indonesia, and, more recently, Tarp, Roland-Holst, and Rand (2002), and Debowicz (2016) prepared SAMs for Vietnam and Iraq, respectively. A common objective of the above-mentioned studies was to highlight the structural and functional impacts of the different multipliers caused by an increase in demand. These analyses examined the macro impacts in general and across different household groups in particular. However, since the SAM is a countryspecific framework capturing the economic situation of the country for which it is designed, the outcomes varied among them.

In the context of Malaysia's SAM literature in more detail, Zakariah (2007) in formulating the income distribution issues addressed in the Ninth Malaysia Plan 2006-2010 (Economic Planning Unit, 2006), contributed to the SAM construction by adding the compensation of employee numbers in the industrial column's account. Recently, Zakariah et al. (2012) constructed a SAM for Malaysia with 2000 as the base year which disaggregated government expenditure among sectors, however it lacked multiplier analysis to shed light on the impacts of an increase in government investment expenditure. It has been about a decade since the last SAM was constructed for Malaysia, and economic structures have changed in many significant and different aspects. ${ }^{3}$

This makes it difficult to conduct an economy-wide policy analysis to assess the impacts of economic expansion plans designed by the government, although Zakariah (2005) has made major efforts in this direction. On the modelling side, also, the growing dissatisfaction with the previous frameworks called for constructing a new SAM and multiplier analysis that is capable of taking into consideration the existing economic situation in Malaysia. ${ }^{4}$ The aim of this paper is to fill this gap. In other words, the novelty of this paper is that it does not deal with analytical methods, but rather explores the issues and challenges associated with a particular application of SAM generation 
in a context where an up-to-date measured database is lacking. Indeed, a significant limitation in previous Malaysian SAMs which are differentiated in this paper from the developed SAM in the literature is the simplified assumption underlining the saving-investment block. In other words, since this account is known as a residual-balancing condition in the SAM, the numbers in the rows and columns should be calculated from other transaction flows and the interaction's values must reflect the situation in the economy for the benchmark year (which was 2010). The accounts are government budget deficit/surplus and current account balance. Indeed, there are few quantitative research studies identifying the sector with highest contribution in Malaysia's economic growth and generation of income.

Therefore, in addition to the application of the new SAM for multiplier analysis purposes, the principal loss in information contains savinginvestments flow for government and the rest of the world, and the disaggregation of government expenditure into current and investment expenditures will be addressed in this paper. It should be noted that the developed SAM was based on the latest Malaysian input-output tables published by the Department of Statistics (2015a) using 2010 as the benchmark year. Data collected for the base year 2010 provides an up-to-date coherent picture of the complexity of the Malaysian economy that takes into account the significant structural changes in the economy since the last SAM was published. In this paper, Section 3 discusses the approach and structure used for estimating the SAM for Malaysia using the latest input-output tables and other data sources. Section 4 discusses the constructed SAM followed by an analysis on assessing the effects of the increase in final demand through conducting a SAM multiplier analysis. Section 5 concludes the paper and provides policy recommendations based on the analysis.

\section{Structure of the Malaysian Social Accounting Matrix}

A SAM is a numerical representation of the linkages between economic agents showing a closed cycle that also takes into account distributive issues. An important characteristic of the SAM framework is the flexibility in presenting country-specificeconomic features and planning priorities. In other words, national priorities are defined through the identification of different economic agents, such as producers, production factors, households, companies, and the government, while the foreign sector shows transactions with the rest of the world. A SAM can be utilised for many different issues and analyses in the field of quantitative research. These issues vary from tax incidence analysis 
to income distribution, sectoral planning and government budget issues. Furthermore, a SAM can be used as the base-year data for a commutable general equilibrium simulation model.

Table 2 shows a schematic representation of the developed macro SAM for Malaysia. Economic inter-linkages are presented for a particular year in a matrix format based on the System of National Accounts (United Nations, 1968) and the input-output framework. As shown, the linkages within the Malaysian economy are represented by 16 accounts and the table tracks income generation and distribution for all of them. The rows show receipts while the columns represent outlays (expenditures). Table 2 depicts how sectoral value-added elements accrue to production factors (capital and labour) and their owners (households), how the income generated is spent through different transactions, and how the consumption of commodities adds value. The interaction between each agent and saving account shows the cycle's leakages. In other words, the row on savings as the residual account allows the row sum for each account to equal the corresponding column sum. For instance, savings from the government account shows the government budget deficit or surplus as the difference between government receipts and expenditures. In turn, the linkages between capital and savings present a glimpse of the dynamics in the cycle.

As shown in Table 2, the transaction's cells are categorised into three types, two grey-shaded and one without shading. The accounts which are shown without the grey shade show that the data for these cells are extracted from the input-table or the Use and Make matrices. Some other cells are differentiated through light and dark grey shades. The shaded area generally shows that the data for these accounts are drawn elsewhere or not found in the input-output table. Furthermore, entries in dark grey depict transactions which are not shown in the previously compiled SAM for Malaysia in the literature. From the technical point of view, as the Malaysian economy is a developing open economy, transactions between production factors and the foreign sector also need to be shown accurately, which have been omitted in the developed SAMs previously found in the literature. This paper fills this technical gap as well by including these flows within the corresponding cells.

Regarding the objectives of this paper, Table 2 shows 16 accounts grouped into eight broad accounts that include production activities, source-specific commodities (domestic and imported), factors of production (labour and capital), taxes (indirect and direct), institutions (households, companies, and the public sector), investment-savings, stocks, and the rest of the world (ROW). Various commodities produced 
by multi-production producers are consumed as domestic intermediate use $(2,1)^{5}$ or consumed by final demand as households $(2,10)$, government current and investment expenditures $(2,12)$ and $(2,13)$ respectively, private investment (2,14), change in inventories (2,15), and to the ROW as exported commodities $(2,16)$. From the producers' perspective, intermediate inputs are employed from domestic and imported commodities $(2,1)$ and $(3,1)$ respectively, production factors as labour and capital, $(4,1)$ and $(5,1)$ respectively, and pay indirect taxes such as production taxes $(6,1)$ and sales taxes $(7,1)$. The equity between each industry's row and the corresponding column shows that industry's total cost is equal to total output for each industry.

The imported commodity's row and column show that imported commodities (total supply) valued at cost, insurance, freight (CIF) prices, plus import tariff are identical to aggregate sales (total demand) for tariff inclusive of the basic price of imported commodities. In line with other frameworks, this SAM assumes that the household is the owner of production factors and receives revenue from supplying these factors.

More specifically, households receive wages from labour supply $(10,4)$ and capital returns from supplying the capital $(10,5)$. There are three more sources for household income, namely transfers from companies $(10,11)$, transfers from government $(10,12)$, and transfers from ROW $(10,16)$. On the expenditure side, households pay for commodity consumption for domestically-produced $(2,10)$ and for imported-based commodities $(3,10)$. Indeed, households pay consumption taxes as indirect taxes for consuming commodities $(7,10)$ and direct taxes in terms of income taxes $(9,10)$. After deducting the payments to the $\operatorname{ROW}(16,10)$ from household's income, households save the rest of their net income $(14,10)$.

Companies also own capital factors and receive income from supplying capital $(11,5)$. Two other major sources of company's income are transfers paid by the government sector $(11,12)$ and income received from the ROW $(11,16)$. The collected revenues are expended through payments for income tax $(9,11)$, transfers to households $(10,11)$, and transfers to the ROW $(16,11)$. The rest of company's income is defined as its savings $(14,11)$.

Meanwhile, the government sector consists of two distinct accounts as government consumption (which refers to government current expenditure) and government investment (government development expenditure). In terms of government revenue, this sector collects indirect taxes in the form of production tax $(12,6)$, and 
IJMS 24 (1), 139-167 (2017)

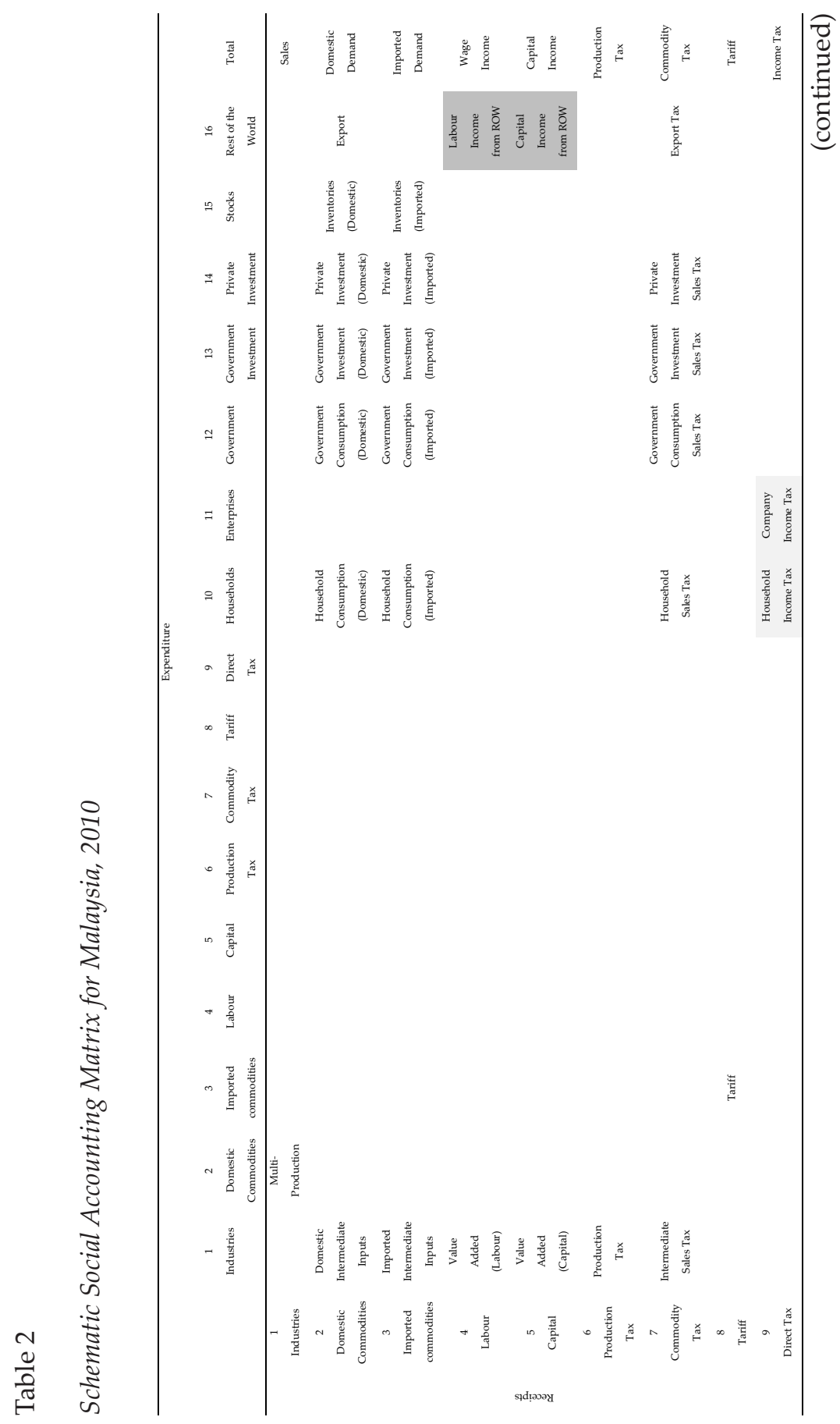


IJMS 23 (2), 139-167 (2017)

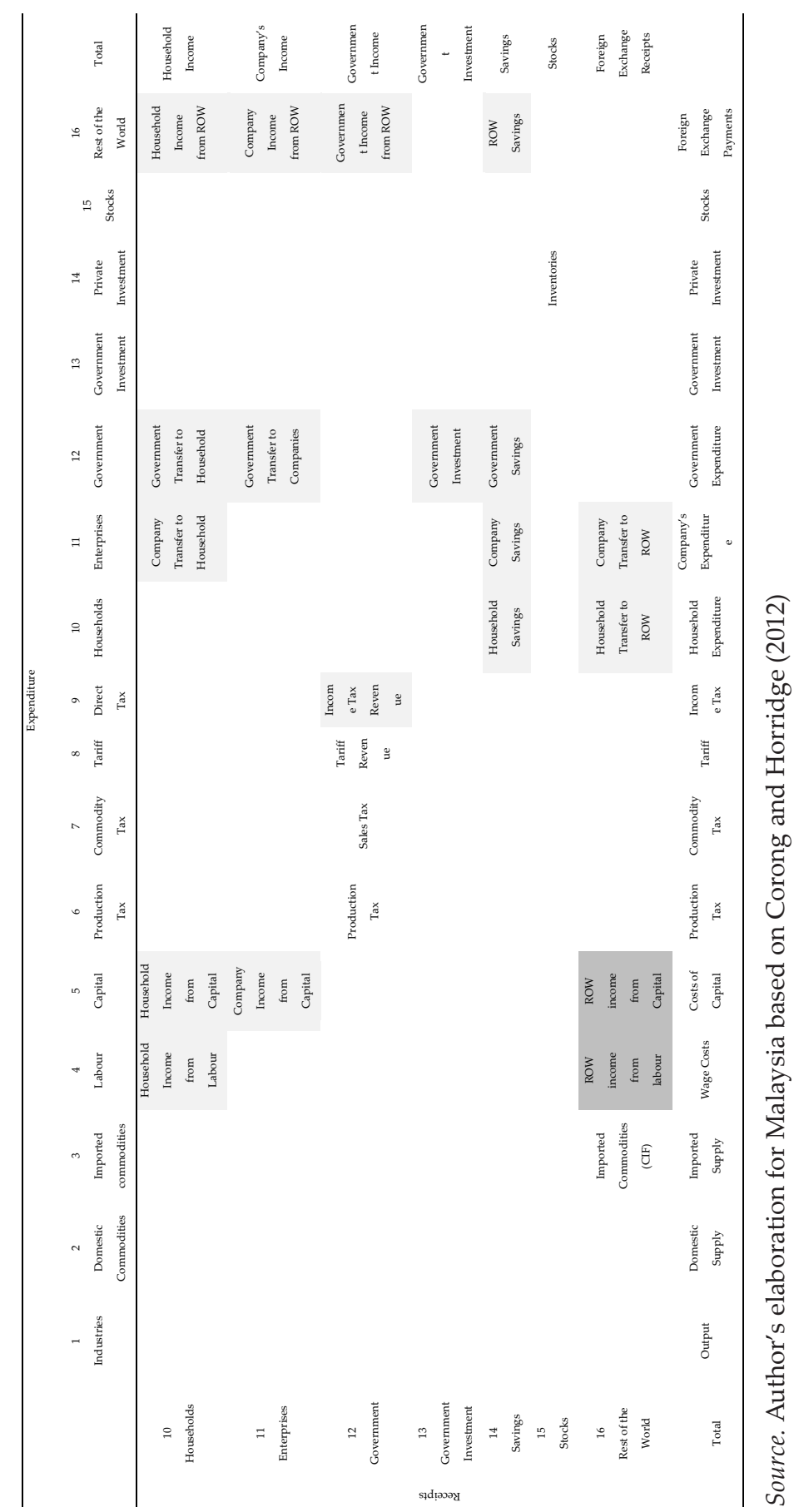


total sales taxes $(12,7)$ and tariffs collected on imported commodities $(12,8)$, and direct taxes in the form of household and company income taxes $(12,9)$. The government also receives revenue from the ROW account $(12,16)$. In terms of government expenditure, expenses are for domestic consumption $(2,12)$ and imported commodities $(3,12)$, to pay sales taxes on commodities $(7,12)$, and to transfer to households and companies, $(10,12)$ and $(11,12)$, respectively. The residual from government income and expenditure (budget deficit/surplus) is shown in the government saving cell $(14,12)$. In terms of government investment account, government consumes domestic $(2,13)$ and imported commodities $(3,13)$ for national development purposes. The government's investment block also pays for sales taxes for consuming source-specific commodities $(7,13)$. The ROW account captures commodity flows between Malaysia and ROW as exports $(2,16)$ and imports $(16,3)$ on the one side, and tracks transactions between domestic and foreign residents located in Malaysia or abroad, on the other side. More specifically, ROW receives income from supplying commodities to Malaysia's market $(16,3)$ and labour $(16,4)$, and capital $(16,5)$. Households pay remittances to the $\operatorname{ROW}(16,10)$, while the last income source of ROW is through transfers by companies $(16,11)$. Total revenues will be consumed through receiving Malaysia-produced commodities $(2,16)$, payment to labour $(4,16)$ and capital $(5,16)$, paying export tax to the government $(7,16)$, and payments to households $(10,16)$, companies $(11,16)$, and the government $(12,16)$, accordingly.

The rest of the revenues after accounting for expenditures will be saved in private savings accounts $(14,16)$. It should be noted that this cell reflects the current account balance of Malaysia. The total savings from all blocks will be consumed as private investment for creating a new unit of capital. In other words, private investment expenditures on domestic $(2,14)$ and imported commodities $(3,14)$, sales taxes $(7,14)$ and changes in inventories $(15,14)$, will be equal to total savings received from all agents. Based on the schematic Malaysia SAM presented in Table 2, Table 3 shows the developed macro SAM in this paper in numerical format. The next section explains the construction process and tries to answer the research questions using multiplier analysis.

\section{Malaysia's Economic Linkages and Multiplier Analysis}

Table 3 shows the constructed 2010 macro SAM for Malaysia. ${ }^{6}$ In developing Table 3, different data sources such as the latest inputoutput tables for Malaysia, national accounts, and international data sources were used. As such, some explanatory notes on the technical 
aspects of the developed SAM will be discussed in this section. The 2010 macro SAM for Malaysia is a square matrix that includes 16 accounts with entries along the column showing the account's expenditures, while entries in rows track receipts (see Table 3). Data for the first eight rows were taken from Malaysia's 2010 input-output tables (Department of Statistics, 2015a). Data for the intersection of the government row and the tax column accounts, except for income taxes, were computed from the Use tables for domestic and imported tax on commodities of the input-output table. Data for entries along the other rows and columns were not found in the input-output table and drawn from national and international databases.

A notable feature of Table 3 is that in compiling the industry and commodity accounts, commodities by industry Use tables were utilised to present the relevant linkages within the accounts and to make the constructed framework as reflective of Malaysia's real economic situation as possible. In other words, the SAM in this paper distinguishes between commodities and activities. Activities or industries produce goods and services, while commodities are those goods and services which are produced by industries alone. These accounts were separated since when the off-diagonal entries of a MAKE matrix are not zero, it reflects that an industry produces more than one commodity and accordingly, a commodity can be produced by more than one industry. ${ }^{7}$ The equal numbers in row and column 1 show that the total cost of production in each industry is equal to the total production for that industry. Row and column 2 also show that the total commodity output from MAKE matrix is equal to total domestic demand plus export demand, and this account is referred to as a Supply-Use table depicting that for each commodity produced, total output is equal to its total demand.

Regarding the real economic situation of Malaysia and data availability, additional flows were introduced in the constructed SAM in this paper. Flows representing labour and capital payments from the rest of the world can be added to the intersection on the labour row and ROW column. Indeed, the entries along the intersection of the ROW and labour and capital column accounts, representing factor payments to ROW, are computed from World bank data valued in current local currency units for 2010 (World Bank, 2016). ${ }^{8}$ The following entry at the intersection of the company's row and capital column accounts was estimated from the difference between the capital column and payments to the ROW from this factor. The value 
of transfer from the company's row and column was also extracted from the World Bank (2016) database for Malaysia.

The intersection of the company's account and government refers to the enterprise tax and was gathered from the World Bank database. Since the World Bank's development indicator for Malaysia was prepared based on data on current transfers from abroad to Malaysian companies, it can be inserted in the intersection of the institution row and the ROW column. The intersection of the capital row and company column exhibits the gross savings available in the World Bank database (2016). Closer observation of Table 3 reveals that capital factors receive higher incomes when compared with labour. ${ }^{9}$ In other words, when the company's revenue from capital is included in the calculation of total factor income, the capital factor receives higher income from its supply, and when company's revenues are excluded, labour receives higher income. An analysis of the share of labour and capital (land inclusive) in the developed SAM identified that the agricultural and service sectors generate the highest income for labour while the energy sector especially oil and gas, and electricity, stone and clay mining, and the dairy product sectors generate higher income for capital suppliers.

The commodity taxes demonstrated in the SAM are net of subsidies and are net indirect taxes. Commodity taxes are applicable to government, household, and investment consumption. Production taxes are also paid by producers as a production cost and received by the government. Though the net commodity tax is a component of government revenue, Table 3 shows it in a separate account to ease presentation of the detailed structure of taxes as indirect and direct taxes. The decomposition of net commodity taxes across production sectors was done with the help of the 2010 input-output table.

The value of indirect tax income, in the intersection of the government row and commodity tax column, was calculated by summing the commodity tax row for all users. Finally, as depicted in Section 3, each factor consumes its receipts and saves the remaining income. In other words, the intersections between the private saving row and other institution's column show the residual calculation from total income and total expenditure for each agent. ${ }^{10}$ Then, total private investment including change in inventories must be equal to total private savings. 
IJMS 23 (2), 139-167 (2017)

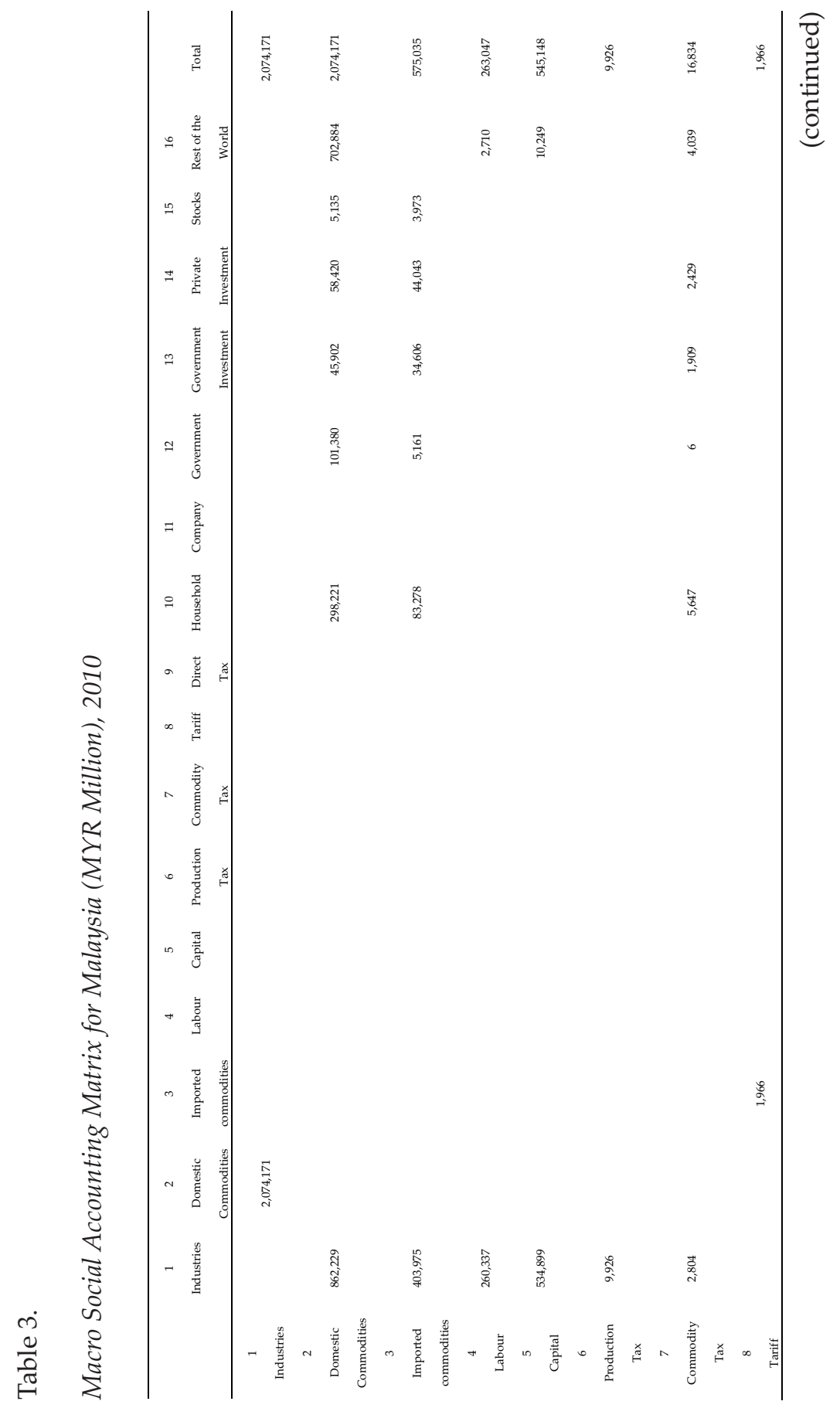


IJMS 24 (1), 139-167 (2017)

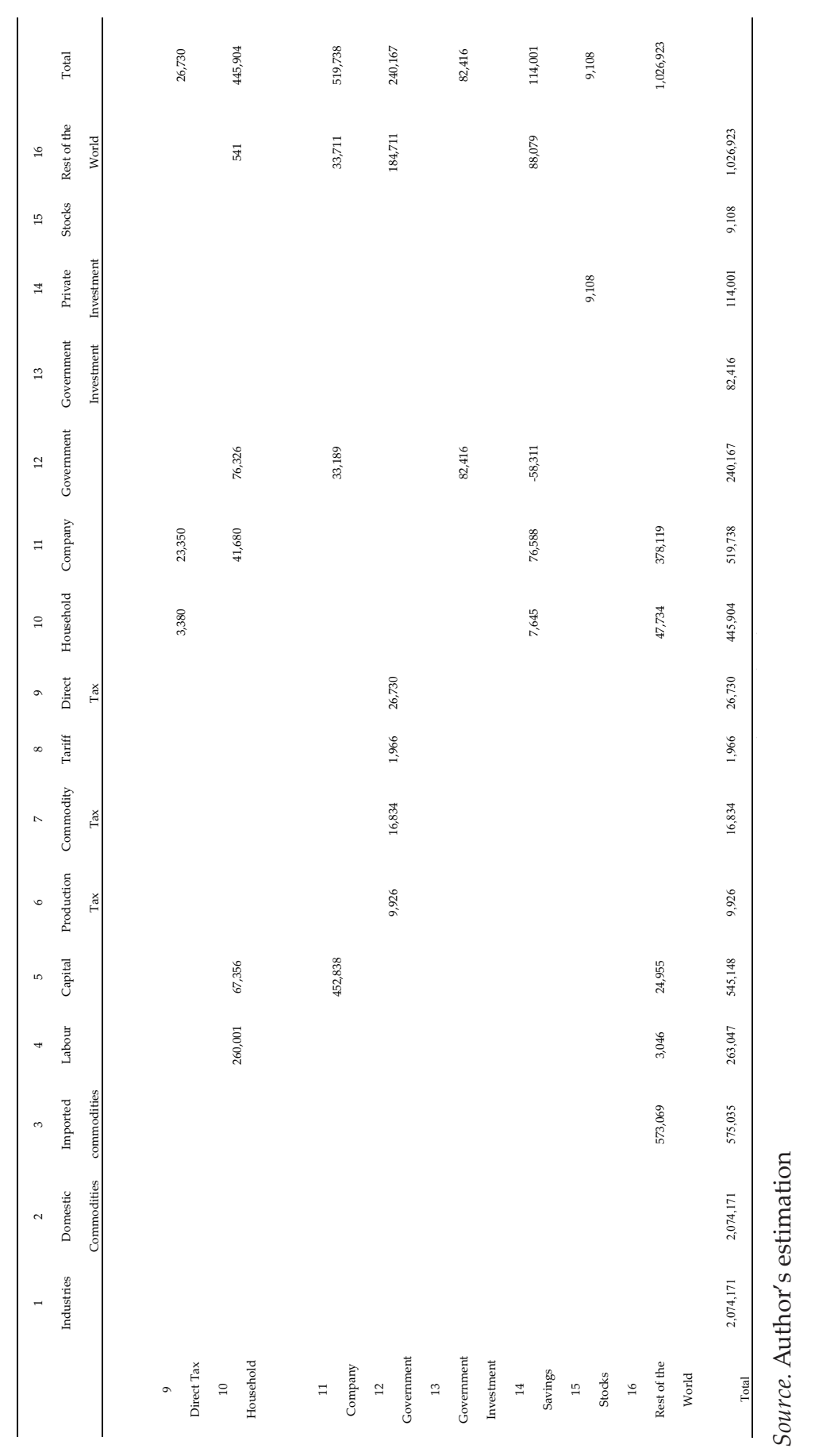


In respect to this identity, in terms of the government account, the difference between total government revenue and expenditure should represent Malaysia's fiscal deficit for 2010, if expenditure exceeds revenue. As Table 3 shows, the entity for government savings is equal to MYR58 billion. Since Malaysia's fiscal account ran a budget deficit equal to $-5.6 \%$ of Malaysia's GDP in 2010 (Central Bank of Malaysia, 2010), this value also shows a deficit equal to that in 2010, as shown in Table 3. Indeed, the private savings account (household plus companies' savings) is shown by a positive value recording about MYR82 billion. Also, as shown, in terms of the balance of payment account, Malaysia recorded MYR88 billion surpluses in the current account balance. This means that Malaysia's foreign exchange receipts exceeded imports and transfers to foreigners. ${ }^{11}$ Passing these validity measurements gives more accuracy to the constructed SAM in this paper.

Based on the above discussion, the constructed SAM framework in this paper differs from the previously developed SAM for Malaysia in the following ways:

- the government expenditure account differentiates between current and investment expenditures;

- households are disaggregated into three categories, i.e., rural, urban, and non-residents, and accordingly, the labour factor is aggregated into these sub-types and the linkages between labour income for households and income tax accounts for each group are identified separately;

- detailed treatment of direct and indirect taxes in the government account, where the former includes income taxes paid by different household types and companies, while the latter comprises sale taxes, production taxes, export taxes, and import tariffs;

- the constructed framework distinguishes between commodities and activities, and a detailed 124×124 dimensional MAKE matrix is used to construct entries for intersections for industry by commodity blocks;

- the matrix of this paper fills the gap for the lack of intersections between ROW and primary factors such as labour and capital; and

- private savings account fills out as a residual to check the quality of the constructed framework. Comparing the values for intersections between the private savings row and three major accounts with Malaysia's actual data conforms to the accuracy of the framework. These measures are government fiscal accounts, current account balance, and the value of private savings in the economy. 
According to the developed SAM in Table 3, the rest of this section presents the results for the multiplier analysis. Stimulating aggregate demand is among Malaysia's strategies for achieving the objective of becoming a high-income economy by 2020 (Economic Planning Unit, 2011). Relying on the constructed SAM in this paper, the effects of an external demand-side shock equivalent to the injection of MYR1 million at 2010 constant prices will be highlighted. For this analysis, it was assumed that the quantities in the model have linear relationships ${ }^{12}$ and that prices are fixed. ${ }^{13}$

Table 4 shows three different multiplier effects resulting from the increase in final demand in terms of output, value-added elements (GDP), and total and household type specific income for 45 (out of 124) sectors in the SAM. This table depicts different SAM rather than input-output multipliers and therefore includes all types of linkages and for all rounds. It should be noted that since the household sector was determined endogenously in the model, other components of final demand stimulus were assumed exogenous. These components comprised companies, government consumption and investment, private investment, stocks, and export demands. In other words, the multiplier would show the effect on endogenous accounts of household and producers resulting from an exogenous shock in demand for the above mentioned exogenous accounts. The method for conducting this type of multiplier is discussed in detail in Breisinger, Thomas, and Thurlow (2009).

Table 4

Multipliers-Impacts of 1 MYR Million Increase in Final Dema

\begin{tabular}{lcccccc}
\hline Sector & Multiplier & \multicolumn{7}{c}{} & \\
\cline { 2 - 7 } & Output & $\begin{array}{c}\text { Value } \\
\text { Added }\end{array}$ & Income & $\begin{array}{c}\text { Income- } \\
\text { Rural }\end{array}$ & $\begin{array}{c}\text { Income- } \\
\text { Urban }\end{array}$ & $\begin{array}{c}\text { Income- } \\
\text { Non- } \\
\text { Citizen }\end{array}$ \\
\hline Paddy & 1.59 & 1.34 & 0.36 & 0.19 & 0.16 & 0.00 \\
Food Crops & 1.61 & 1.00 & 0.33 & 0.17 & 0.15 & 0.01 \\
Rubber & 2.03 & 1.07 & 0.35 & 0.15 & 0.20 & 0.00 \\
Oil Palm & 1.66 & 1.01 & 0.30 & 0.11 & 0.16 & 0.03 \\
Flower Plants & 1.55 & 1.02 & 0.28 & 0.06 & 0.20 & 0.02 \\
Other Mining & 1.85 & 0.91 & 0.32 & 0.09 & 0.18 & 0.05 \\
and Quarrying & & & & & & \\
\hline
\end{tabular}

(continued) 
IJMS 23 (2), 139-167 (2017)

\begin{tabular}{|c|c|c|c|c|c|c|}
\hline \multirow[t]{2}{*}{ Sector } & \multicolumn{6}{|c|}{ Multiplier } \\
\hline & Output & $\begin{array}{l}\text { Value } \\
\text { Added }\end{array}$ & Income & $\begin{array}{l}\text { Income- } \\
\text { Rural }\end{array}$ & $\begin{array}{c}\text { Income- } \\
\text { Urban }\end{array}$ & $\begin{array}{l}\text { Income- } \\
\text { Non- } \\
\text { Citizen }\end{array}$ \\
\hline $\begin{array}{l}\text { Petroleum } \\
\text { Refinery }\end{array}$ & 1.93 & 0.81 & 0.18 & 0.03 & 0.14 & 0.01 \\
\hline $\begin{array}{l}\text { Electricity and } \\
\text { Gas }\end{array}$ & 1.78 & 0.78 & 0.19 & 0.03 & 0.15 & 0.00 \\
\hline $\begin{array}{l}\text { Crude Oil and } \\
\text { Natural Gas }\end{array}$ & 1.41 & 0.99 & 0.20 & 0.04 & 0.15 & 0.01 \\
\hline $\begin{array}{l}\text { Meat and Meat } \\
\text { Production }\end{array}$ & 2.71 & 0.82 & 0.36 & 0.07 & 0.28 & 0.00 \\
\hline $\begin{array}{l}\text { Preservation of } \\
\text { Seafood }\end{array}$ & 2.91 & 0.89 & 0.34 & 0.08 & 0.25 & 0.01 \\
\hline $\begin{array}{l}\text { Preservation } \\
\text { of Fruits and } \\
\text { Vegetables }\end{array}$ & 2.25 & 0.69 & 0.28 & 0.06 & 0.21 & 0.00 \\
\hline $\begin{array}{l}\text { Dairy } \\
\text { Production }\end{array}$ & 2.25 & 0.67 & 0.20 & 0.04 & 0.15 & 0.01 \\
\hline Oils and Fats & 3.01 & 0.95 & 0.31 & 0.10 & 0.19 & 0.02 \\
\hline Grain Mills & 2.19 & 1.11 & 0.34 & 0.12 & 0.22 & 0.00 \\
\hline $\begin{array}{l}\text { Veneer Sheets, } \\
\text { Plywood, } \\
\text { Laminated } \\
\text { Board }\end{array}$ & 2.83 & 0.78 & 0.28 & 0.06 & 0.21 & 0.01 \\
\hline $\begin{array}{l}\text { Builders' } \\
\text { Carpentry and } \\
\text { Joinery }\end{array}$ & 2.90 & 0.88 & 0.35 & 0.06 & 0.28 & 0.01 \\
\hline $\begin{array}{l}\text { Wooden and } \\
\text { Cane Containers }\end{array}$ & 3.01 & 0.91 & 0.36 & 0.11 & 0.25 & 0.01 \\
\hline $\begin{array}{l}\text { Electrical } \\
\text { Machinery and } \\
\text { Apparatus }\end{array}$ & 1.95 & 0.46 & 0.20 & 0.03 & 0.16 & 0.00 \\
\hline $\begin{array}{l}\text { Rubber } \\
\text { Processing }\end{array}$ & 2.60 & 0.57 & 0.21 & 0.06 & 0.14 & 0.00 \\
\hline Rubber Gloves & 2.77 & 0.58 & 0.21 & 0.05 & 0.15 & 0.00 \\
\hline $\begin{array}{l}\text { Rubber } \\
\text { Products }\end{array}$ & 2.79 & 0.57 & 0.20 & 0.05 & 0.15 & 0.00 \\
\hline $\begin{array}{l}\text { Concrete \& } \\
\text { Other Non- } \\
\text { Metallic Mineral }\end{array}$ & 2.56 & 0.78 & 0.26 & 0.05 & 0.21 & 0.00 \\
\hline $\begin{array}{l}\text { Domestic } \\
\text { Appliances }\end{array}$ & 1.80 & 0.55 & 0.22 & 0.03 & 0.17 & 0.02 \\
\hline
\end{tabular}


IJMS 24 (1), 139-167 (2017)

\begin{tabular}{|c|c|c|c|c|c|c|}
\hline \multirow[t]{2}{*}{ Sector } & \multicolumn{6}{|c|}{ Multiplier } \\
\hline & Output & $\begin{array}{l}\text { Value } \\
\text { Added }\end{array}$ & Income & $\begin{array}{c}\text { Income- } \\
\text { Rural }\end{array}$ & $\begin{array}{l}\text { Income- } \\
\text { Urban }\end{array}$ & $\begin{array}{l}\text { Income- } \\
\text { Non- } \\
\text { Citizen }\end{array}$ \\
\hline Residential & 2.59 & 0.92 & 0.47 & 0.09 & 0.36 & 0.02 \\
\hline Non-Residential & 2.53 & 0.88 & 0.45 & 0.06 & 0.36 & 0.02 \\
\hline $\begin{array}{l}\text { Other Transport } \\
\text { Services }\end{array}$ & 2.47 & 0.78 & 0.31 & 0.04 & 0.25 & 0.01 \\
\hline Banks & 2.28 & 1.21 & 0.52 & 0.06 & 0.45 & 0.01 \\
\hline $\begin{array}{l}\text { Financial } \\
\text { Institution }\end{array}$ & 2.76 & 1.06 & 0.45 & 0.05 & 0.39 & 0.01 \\
\hline Insurance & 2.15 & 1.14 & 0.44 & 0.05 & 0.39 & 0.01 \\
\hline $\begin{array}{l}\text { Other Financial } \\
\text { Institution }\end{array}$ & 2.62 & 1.12 & 0.51 & 0.05 & 0.45 & 0.01 \\
\hline Real Estate & 2.30 & 1.03 & 0.39 & 0.07 & 0.31 & 0.02 \\
\hline $\begin{array}{l}\text { Ownership of } \\
\text { Dwellings }\end{array}$ & 1.62 & 1.05 & 0.20 & 0.04 & 0.15 & 0.00 \\
\hline $\begin{array}{l}\text { Rental and } \\
\text { Leasing }\end{array}$ & 2.11 & 0.91 & 0.32 & 0.06 & 0.25 & 0.01 \\
\hline $\begin{array}{l}\text { Research and } \\
\text { Development }\end{array}$ & 2.12 & 1.32 & 0.80 & 0.15 & 0.62 & 0.02 \\
\hline Professional & 2.10 & 1.11 & 0.48 & 0.05 & 0.41 & 0.01 \\
\hline $\begin{array}{l}\text { Business } \\
\text { Services }\end{array}$ & 2.30 & 0.98 & 0.38 & 0.06 & 0.31 & 0.01 \\
\hline $\begin{array}{l}\text { Public } \\
\text { Administration }\end{array}$ & 2.52 & 1.20 & 0.78 & 0.13 & 0.63 & 0.02 \\
\hline Education & 2.34 & 1.34 & 0.91 & 0.24 & 0.66 & 0.02 \\
\hline Health & 2.20 & 0.98 & 0.59 & 0.09 & 0.49 & 0.01 \\
\hline $\begin{array}{l}\text { Defence and } \\
\text { Public Order }\end{array}$ & 2.51 & 0.98 & 0.57 & 0.10 & 0.45 & 0.01 \\
\hline $\begin{array}{l}\text { Other Public } \\
\text { Administration }\end{array}$ & 2.37 & 1.39 & 0.97 & 0.19 & 0.76 & 0.02 \\
\hline $\begin{array}{l}\text { Private Non- } \\
\text { Profit Institution }\end{array}$ & 2.11 & 1.09 & 0.48 & 0.09 & 0.39 & 0.01 \\
\hline $\begin{array}{l}\text { Amusement and } \\
\text { Recreational } \\
\text { Services }\end{array}$ & 2.31 & 0.82 & 0.42 & 0.05 & 0.36 & 0.01 \\
\hline $\begin{array}{l}\text { Other Private } \\
\text { Services }\end{array}$ & 1.80 & 1.08 & 0.37 & 0.07 & 0.30 & 0.00 \\
\hline
\end{tabular}

Source. Author's calculation 
Table 4 shows that in terms of output multipliers, oil and fats, wood, and preservation of seafood would be affected more, as compared to the manufacturing and service sectors. For example, the results showed that a direct increase equal to MYR1 million in exogenous demand for the oil and fats ${ }^{14}$ commodity would increase aggregate output in the economy by more than MYR3 million when all linkages have been considered. Comparing the values for output and valueadded multipliers showed that output multipliers are larger than value-added ones. This was due to the interlinkages existing between industries and captured by the multiproduction matrix included in the SAM of this study. In relation to the value-added multiplier, a closer observation of Table 4 shows that service-based sectors such as education, research and development, and public administration had the highest increase in value-added elements. This result is expected since the increase in government expenditure will stimulate additional production in these sectors (because government only consumes services) and higher value-added elements in the form of wages are paid for the labour factor within these sectors.

An important result seen from the table is that the values of income multipliers across all sectors are lower than that for output multipliers. This is due to the leakage effect ensuing from the circular factor income which is paid for direct taxes, indirect taxes, and imports (see Table 3 for these leakages). According to the results presented in Table 4 , comparing the values for different multipliers and across different sectors sheds light on the structural characteristics of the Malaysian economy. The agricultural sector has stronger linkages compared to the manufacturing, service-based, and construction sectors. The interlinkages between agricultural products shown in Malaysia's multiproduction matrix (MAKE) confirmed this result. In other words, since the activity-by-commodity part of Table 3 is occupied by a multi-product and not a diagonal matrix, the inter-linkage between agricultural products is highlighted more. This effect can also be seen in the rubber-based sectors which are affected much more compared to others in the manufacturing sector. The output multiplier effect for rubber products shows that a MYR1 million expansion in demand in the rubber sector will contribute to almost a threefold increase in output in the economy. The high output multipliers for industries in the agricultural sector also reflect their stronger inter-linkages with other sectors in the economy (this highlights the importance of MAKE table in constructing a SAM). In line with Table 4, Figure 5 shows the value-added multipliers across sectors in graphical and trend order forms. Comparing the value for this multiplier produced some interesting results in some sectors. Among them is the value of the 
value-added multiplier for electrical machinery industry (0.46), which revealed an output multiplier equal to 1.95 (Table 4), when this sector is among the highest export oriented and import intensive sectors in Malaysia. The high values depicted by service-based sectors reflect the importance of these sectors as a means for expanding Malaysia's GDP and increasing household income.

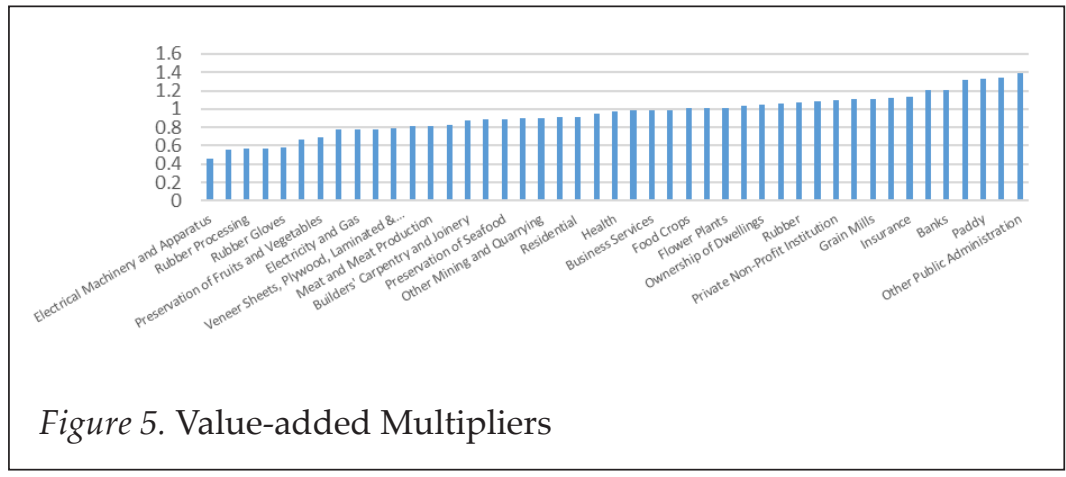

Source. Author's calculation

As shown in Table 4, in terms of income multipliers, rural households would benefit more than their urban counterparts as a result of the increase in demand for agricultural sector goods. This is in line with the share of agricultural commodities in their consumption basket. In other words, since the share of rural households of agricultural goods is higher than non-agricultural commodities, an increase in exogenous demand for these goods increases their output, and in turn raises income of farmers and with relatively lower leakage in the form of income tax. The findings showed that as a result of an exogenous demand stimulus in some sectors, both rural and urban households would benefit. Education, research and development, and public administration are among the top categories in these sectors. Unlike the rural household group, urban households receive higher income from the services and manufacturing sectors, while non-resident households would be much affected by an increase in demand for output from construction, other mining, and the oil and fats sectors.

Generally, the impact of an exogenous demand shock depends on different elements, including the distribution of labour income between households, the share of each commodity in the household expenditure basket, and the share of domestically produced goods in Malaysia. When a higher share of a commodity is produced 
domestically, an increase in its aggregate demand increases revenue for those employed in that particular sector.

\section{Conclusion and Policy Recommendations}

This paper provided an updated and more detailed SAM framework for analysing the Malaysian economy for the year 2010. Subsequently, in identifying which sectors contribute to economic growth, a multiplier analysis of the potential inter-linkages and round-by-round effects of a MYR1 million increase in exogenous demand for outputs from all sectors was carried out. The multiplier analysis included output, value-added elements (GDP), and income distribution elements. The constructed SAM and the results from the multiplier analysis suggest that the input requirements across industries in the Malaysian economy have not changed significantly, and the results are consistent with the structural characteristics of Malaysia, and also consistent with the contributions of each sector to the national GDP. The validation measure shows that the residual of each agent's receipts and expenditures automatically filled up the entries in the private saving's row and each institution's column, and the values conform to the data published by national accounts from the Central Bank of Malaysia.

Using multiplier analysis confirms that the service-based sector contributes the most to Malaysia's economic growth followed by manufacturing (see Figure 2) and this confirms data from other official sources. Distributional effects are also discussed in greater detail. In view of Malaysia's Vision 2020 aspirations, it is recommended, firstly, that the government produce shorter-interval input-output tables for Malaysia, introduce input-output tables for individual states, and update the SAM of this paper to enable a robust empirical and quantitative analysis of the expected economy-wide, sectoral, and distributional effects of different economic policies. Secondly, since the service sectors are the engines for economic growth and income distribution in Malaysia, the government should consider increasing its investment or stimulating private consumption and investment in this sector as a means to accelerate the achievement of Vision 2020 targets.

The results from the three multipliers showed that inter-linkages between agricultural sectors are larger when output multipliers for these sectors are higher compared to manufacturing and service 
sectors. In terms of value-added multipliers, the results showed that the service sector is mostly affected when an increase in exogenous demand leads to an increase in demand for its output which, in turn, raises household income with a higher multiplier factor. Differentiated income multipliers indicate that rural households experience higher increases in income when the agricultural sector experiences a rise in demand for its output. The increase in exogenous demand for education, health, and public defence results in higher household income for both rural and urban groups. Non-citizen households benefit more from the increase in demand for output from construction, oil and fats, and other mining.

These conclusions from a SAM multiplier model assumes that the production factor and domestically produced commodity markets are equilibrated based on changes in quantities and that relative prices are assumed to be fixed. However, in the real Malaysian economy, the relative prices of some commodities such as energy products, namely crude oil and natural gas, are influenced by world markets. As such, future research should employ the constructed SAM in this paper within a computable general equilibrium framework to explore the impacts of exogenous economic policies and target plans in the context of endogenous relative prices.

\section{End Notes}

1 The figures for 2016 are based on national budget estimates.

2 It should be noted that 1970 is the benchmark year for which the SAM is constructed.

3 The official SAM is compiled by Malaysia's government agencies such as the Economic Planning Unit (EPU), and due to socioeconomic concerns, the tables are deemed confidential and not published publicly. Thus, SAM analysis has a relatively short history in Malaysia and there is no officially published data source.

4 For instance, all the Malaysian constructed SAMs in the literature used symmetric commodity by commodity or activity by activity tables. From both, modelling and multiplier viewpoints, this assumption is not the most accurate since the multi-production linkage depicted in the MAKE table is not shown in these analyses.

5 The parentheses show the cell address in Table 2.

6 It should be noted that since the original constructed SAM included 124 commodities and 124 activities, three types of labour and household income groups - rural, urban, and non-citizens-, 
due to space constraints, aggregated accounts are presented in this macro SAM.

7 It should be emphasised that due to simplifying assumptions, the majority of the Malaysian constructed SAM in the literature used commodity by commodity or activity by activity tables (since these tables are originally square and balanced) in their SAM construction process. However, this assumption is not the most relevant since the multi-production linkage depicted in the MAKE table is not shown in these SAM tables (assuming diagonal MAKE matrix). Thus, in constructing the SAM for this paper this issue was addressed.

8 It should be noted that due to the consistency between the data corresponding to the linkages among other institutions rather than those presented by the input-output tables, the data from World Bank for Malaysia for 2010 published in 2016 were used. The checking measurements for the consistency between national data sources such as the Department of Statistics and the Central Bank of Malaysia revealed that the World Bank database is consistent with national data.

9 It should be noted that in constructing the industrial cost structures based on the GTAP database construction method by Aguiar, McDougall, and Narayanan (2012), the capital account includes land and was calculated for the agricultural, mining, and extraction sectors as natural capital-resources. Thus, capital here is inclusive of land values.

10 This account works as a control measurement.

11 It should be noted that these numbers confirmed Malaysia's national account data for 2010 as reported by the Department of Statistics and the Central Bank of Malaysia (2014).

12 This assumes that exogenous change in demand will not affect the structural relationships between households and other sectors, and there is no behavioural change in the economy.

13 Simulating endogenous changes on relative prices as a result of the exogenous shock to demand stimulus calls for designing a Computable General Equilibrium (CGE) model which is beyond the scope of this paper. Therefore, the assumed changes in demand lead to changes in physical output only and prices will not change.

14 Although the oil palm sector is identified separately in the SAM table, the input-output tables for 2010 show that Malaysia's exports of this product was captured under oil and fats, since there are different types of oil palm products such as crude palm oil (CPO) and other derivations. 
IJMS 24 (1), 139-167 (2017)

\section{Acknowledgments}

The authors would like to express their sincere appreciation to the Editor-in-Chief and anonymous referees. This paper is part of the research on the "Designing an Economic Development Plan for Terengganu State 2015-2025" by the Malaysian Institute of Economic Research (MIER).

\section{References}

Aguiar, A., McDougall, R., \& Narayanan, B. (2012). Global Trade, Assistance, and Production: The GTAP 8 Data Base. Center for Global Trade Analysis, Purdue University.

Breisinger, C., Thomas, M., \& Thurlow, J. (2009). Social accounting matrices and multiplier analysis: An introduction with exercises (Vol. 5): Intl Food Policy Res Inst.

Central Bank of Malaysia. (2010). Annual Report. Kuala Lumpur: Bank Negara Malaysia.

Central Bank of Malaysia. (2014). Annual Report. Kuala Lumpur: Bank Negara Malaysia.

Chander, R., Gnasegarah, S., Pyatt, G., \& Round, J. I. (1980). Social accounts and the distribution of income: The Malaysian economy in 1970. Review of Income and Wealth, 26(1), 67-85.

Corong, E., \& Horridge, M. (2012). PHILGEM: A SAM-based computable general equilibrium model of the Philippines: Monash University, Centre of Policy Studies and the Impact Project.

Debowicz, D. (2016). A social accounting matrix for Iraq. Journal of Economic Structures, 5(1), 24.

Defourny, J., \& Thorbecke, E. (1984). Structural path analysis and multiplier decomposition within a social accounting matrix framework. The Economic Journal, 94(373), 111-136.

Department of Statistics. (2015a). Input-Output Tables for Malaysia for 2010. Department of Statistics, Malaysia.

Department of Statistics. (2015b). The Office of Chief Statistician. Malaysia Department of Statistics, Malaysia.

Economic Planning Unit. (2001). Eighth Malaysia Plan 2001-2005. Economic Planning Unit Malaysia.

Economic Planning Unit. (2006). Ninth Malaysia Plan 2006-2010. Malaysia: Economic Planning Unit, Malaysia.

Economic Planning Unit. (2011). Tenth Malaysia Plan 2011-2015. Malaysia: Economic Planning Unit, Malaysia. 
Kehoe, T. J. (1996). Social accounting matrices and applied general equilibrium models: Federal Reserve Bank of Minneapolis Minneapolis, Minnesota.

Keuning, S., Thorbecke, E., \& Morrison, C. (1989). The impact of budget retrenchment on income distribution in Indonesia: A Social Accounting Matrix application: OECD.

Kuznets, S. (1937). Appendices to National Income and Capital Formation, 1919-1935. (pp. 61-90): NBER.

Leontief, W. (1941). The Structure of the American Economy 19191929: An empirical application of equilibrium analysis: Harvard University Press.

Meade, J. E., \& Stone, R. (1941). The construction of tables of national income, expenditure, savings and investment. The Economic Journal, 51(202/203), 216-233.

Ministry of Finance Malaysia. (2016). Federal Government Administrative Centre. Putrajaya, Malaysia.

National Economic Advisory Council. (2010). New Economic Model for Malaysia. National Economic Advisory Council.

Pyatt, G., \& Round, J. I. (1979). Accounting and fixed price multipliers in a social accounting matrix framework. The Economic Journal, 89(356), 850-873.

Pyatt, G., Round, J. I., \& Denes, J. (1984). Improving the macroeconomic data base: A SAM for Malaysia, 1970. World Bank.

Quesnay, F. (1758). Quesnay's Tableau Economique, 1972 edn, eds \& trans. M Kuczynski \& RL Meek: Macmillan, London.

Ramanathan, R. (2012). Introduction to the theory of economic growth (Vol. 205): Springer Science \& Business Media.

Round, J. (1981). Income distribution within a social accounting matrix: a review of some experience in Malaysia and other LDC's, Development Economics Research Centre-University of Warwick: Discussion paper.

Round, J. (2003). Constructing SAMs for development policy analysis: Lessons learned and challenges ahead. Economic Systems Research, 15(2), 161-183.

Stone, R. (1947). Definition and measurement of the national income and related totals. United Nations, Geneva.

Stone, R. (1962). A social accounting matrix for 1960: Department of Applied Economics. University of Cambridge.

Stone, R., \& Brown, A. (1962). A computable model of economic growth (Vol. 1): Chapman and Hall London.

Tarp, F., Roland-Holst, D., \& Rand, J. (2002). Trade and income growth in Vietnam: estimates from a new social accounting matrix. Economic Systems Research, 14(2), 157-184. 
Thorbecke, E. (1992). Adjustment and equity in Indonesia: Development Centre of the Organisation for Economic Co-operation and Development; OECD Publications and Information Centre, distributor].

United Nations. (1968). System of National Accounts (Vol. 2): International Monetary Fund.

World Bank. (2016). World Bank Data Indicators: World Bank Publications.

Zakariah, A. R. (2005). Social Accounting Matrix: Applications in policy formulation. Paper presented at the Proceeding of the National Statistic Conference 2005.

Zakariah, A. R. (2007). Planning for equal income distribution in Malaysia: A general equilibrium approach, Universiti Putra Malaysia Press.

Zakariah, A. R., Mukarammah, H., \& Azali, M. (2012). Constructing a social accounting matrix framework to analyse the impact of public expenditure on income distribution in Malaysia. Jurnal Ekonomi Malaysia, 46(2), 63-83. 